інформатичних спеціальностей педагогічних закладів вищої освіти, так і учнів закладів загальної середньої освіти, сприятиме доцільному набуттю фахових знань, що дасть змогу ефективно використовувати комп'ютерні технології в майбутній професійній діяльності

Список використаних джерел:

1. Карпіловська Є.А. Вступ до прикладної лінгвістики: комп'ютерна лінгвістика: підруч. Донецьк: ТОВ «Юго-Восток, Лтд». 2006. 188 с.

2. Лінгвістичні основи комп'ютерної техніки. URL:

https://otherreferats.allbest.ru/languages/00117518_0.html (дата звернення: 17.03.2019).

3. Навчально-методичний комплекс навчальної дисципліни «Прикладна лінгвістика». URL: http://fif.mdu.edu.ua/wp-content/uploads/2017/07/Prikladna-lingvistika-1-kurs.pdf (дата звернення: 17.03.2019).

4. Основи прикладної лінгвістики: вступ до спеціальності. URL: http://elar.khnu.km.ua/jspui/bitstream/123456789/6085/1/текст\%20друк\%20192\%20c.-3.doc） (дата звернення: 17.03.2019).

5. Навчальна програма з дисципліни «Лінгвістична інформатика». / упоряд.: Н.П. Франчук. Київ: НПУ імені М.П. Драгоманова. 2018. 20 с

\title{
References:
}

1. Karpilovs'ka YE.A. Vstup do prykladnoyi linhvistyky: komp"yuterna linhvistyka: pidruch. Donets'k: TOV «Yuho-Vostok, Ltd», 2006. 188 s.

2. Linhvistychni osnovy komp'yuternoyi tekhniky. URL: https://otherreferats.allbest.ru/languages/ 00117518_0.html (data zvernennya: 17.03.2019).

3. Navchal'no-metodychnyy kompleks navchal'noyi dystsypliny «Prykladna linhvistyka». URL: http://fif.mdu.edu.ua/wp-content/uploads/2017/07/Prikladna-lingvistika-1-kurs.pdf (data zvernennya: 17.03.2019).

4. Osnovy prykladnoyi linhvistyky: vstup do spetsial'nosti. URL: http://elar.khnu.km.ua/jspui/ bitstream/123456789/6085/1/текст\%20друк\%20192\%20c.-3.doc (data zvernennya: 17.03.2019).

5. Navchal'na prohrama z dystsypliny «Linhvistychna informatyka». / uporyad.: N.P. Franchuk. Kyyiv: NPU imeni M.P. Drahomanova. 2018. $20 \mathrm{~s}$.

Theoretical aspects of the study of "linguistic informatics" as an applied linguistic discipline Franchuk N.P.

Abstract. This paper some aspects of development of modern applied linguistics. Disclosed content of the academic discipline "Linguistic Informatics". Described five component methodical system of training course "Linguistic science" as a special course for students.

Keywords: linguistic informatics, methodical system of training, special course for students.

DOI 10.31392/NPU-nc.series 2.2019.21(28).14

УДК: 378.147/.148+373.51

О.Н. Кушнір

кандидат педагогічних наук, доцент, декан факультету комп'ютерних наук, фізики та математики

Херсонський державний університет;

В.В. Шакотько

кандидат педагогічних наук, заступник директора з навчальної роботи

Кременчуцький педагогічний коледж імені А.С. Макаренка

\section{ФОРМУВАННЯ АЛГОРИТМІЧНИХ КОМПЕТЕНТНОСТЕЙ МАЙБУТНІХ УЧИТЕЛІВ ІНФОРМАТИКИ НА НОВОМУ ЕТАПІ РОЗВИТКУ ОСВІТИ}

Анотація. У статті проаналізовано погляди вчених на алгоритмічну складову підготовки майбутніх вчителів інформатики, досліджені зв'язки змісту вимог до фахових компетентностей вчителів інформатики та змісту навчальних програм шкільної інформатики на різних етапах розвитку цієї навчальної дисципліни.

Проведено порівняльний аналіз вимог до рівня сформованості алгоритмічних компетентностей учнів середньої школи за програмами інформатики 2008-2009 років та 2017-2018 років. На основі цього аналізу, а також результатів моніторингу рівня підготовленості вчителів до навчання учнів алгоритмізації та програмування обгрунтована необхідність внесення суттєвих змін в методичну 
систему підготовки майбутніх вчителів інформатики, посилення фундаментальної складової цієї системи на основі удосконалення підготовки з алгоритмізації та програмування.

Ключові слова: інформатика, алгоритм, алгоритмічні компетентності, підготовка вчителів інформатики.

Розвиток системи середньої та вищої освіти в Україні передбачає не тільки внесення змін в систему взасмин педагога та учня, «запровадження нового принципу педагогіки партнерства, що грунтується на співпраці учня, вчителя і батьків; підвищення мотивації вчителя шляхом підвищення рівня його оплати праці, надання академічної свободи та стимулювання до професійного зростання...» але i формування в учнів і відповідно у майбутніх учителів компетентностей «необхідних для успішної самореалізації особистості», виховання цілісної всебічно розвиненої особистості, здатної до критичного мислення [12, С. 2].

Систему компетентностей, яка повинна бути сформована у майбутнього вчителя інформатики в ході його професійної підготовки, не можна відривати від вимог до системи інформатичних компетентностей, формування яких у учнів середньої школи повинен забезпечувати учитель інформатики. Система інформатичних компетентностей учня повинна бути складовою системи інформатичних компетентностей учителя інформатики. Тому будь які зміни у вимогах суспільства до рівня сформованості інформатичних компетентностей випускника школи повинні викликати зміни в змісті підготовки вчителя. Необхідно визначити, які зміни у змісті шкільного курсу інформатики передбачені оновленими державними стандартами та навчальними програмами середньої школи і на цій основі змоделювати зміни компонентів методичної системи підготовки вчителя інформатики.

Проблеми, пов'язані з формуванням алгоритмічного мислення учнів в курсі інформатики досліджувались 3 часу введення цього предмету у навчальні плани середньої школи. А.П. Єршов, один 3 авторів і редакторів перших шкільних підручників 3 інформатики, підкреслював важливість програмування в формуванні алгоритмічного, операційного мислення, яке в свою чергу необхідне для успішної діяльності людини в XXI столітті, бо «ми живемо в світі програм, і самі постійно програмуємо, не усвідомлюючи цього... Практично вся область виробничих відносин... - це робота за програмами... Навіть навчання, тобто оволодіння знаннями, або точніше здатності щось зробити, це програмування... Повсякденне життя людини, особливо міське, - це діяльність за програмами.» [1, С. 92-93]. Він розглядав формування алгоритмічного, операційного та комбінаторного мислення, здатності до абстракції як засіб фундаменталізації програмування і в цілому змісту інформатики [1, С. 96-97]. А.П. Єршов запропонував такі основні наукові напрямки інформатики [2].

- теоретичні основи обчислювальної техніки;

- статистична теорія інформації;

- теорія математичного моделювання і обчислювального експерименту;

- алгоритмізація;

- програмування;

- штучний інтелект;

- інформологія.

В подальшому проблеми формування алгоритмічного мислення учнів середньої школи та майбутніх вчителів інформатики досліджували С.О. Бешенков, Ю.В. Горошко, Л.І. Білоусова, М.І. Жалдак, В.М. Касаткін, О.А. Кузнєцов, М.П. Лапчик, В.М. Монахов, Н.В. Морзе, С.А. Раков, Ю.С. Рамський, І.Г. Семакін, С.О. Семеріков, Т.В. Тихонова, Ю.В. Триус та ін.

Враховуючи, що обсяги нових відомостей щоденно зростають високими темпами, гострою постає проблема фундаменталізації шкільного та університетського курсу інформатики. Фундаменталізація передбачає орієнтацію в змісті дисципліни на методологічно значимі, системоутворюючі поняття, які не мають швидкоплинного характеру, не мають тенденції до швидкої зміни і $\epsilon$ теоретичною основою інформатики. На думку М.І. Жалдака, К.К. Коліна, С.А. Ракова, Ю.С. Рамського, С.О. Семерікова та інших до фундаментальних основ інформатики належить теорія алгоритмів.

Питання проектування та реалізації методичних систем підготовки майбутніх вчителів інформатики, формування професійних компетентностей вчителів інформатики досліджували С.О. Бешенков, М.І. Жалдак, О.А. Кузнецов, М.П. Лапчик, Н.В. Морзе, С.А. Раков, Ю.С. Рамський, І.Г. Семакін, О.Я. Фрідланд та інші.

Значна частина вчених в структурі професійних компетентностей вчителя виокремлює окремою складовою алгоритмічні компетентності. Так на думку С.А. Ракова серед інших складових інформаційно-комунікаційних компетентностей слід зазначити алгоритмічну складову усвідомлення комп'ютера як універсального виконавця алгоритмів і як універсального засобу 
конструювання алгоритмів; володіння базовими поняттями теорії алгоритмів, володіння сучасними засобами конструювання алгоритмів [15].

П.В. Нікітін, Р.І. Горохова, А.І. Мельникова пропонують, враховуючи завдання, що повинен виконувати вчитель інформатики в професійній діяльності, виокремити такі предметні компетентності в галузі інформатики: користувацькі компетентності, компетентності в галузі програмування, компетентності в галузі мультимедіа, компетентності в галузі мережевих технологій. А для формування компетентностей в галузі програмування реалізувати виконання таких завдань навчання: навчання основ алгоритмізації, процедурного та об'єктно-орієнтованого програмування, web-програмування, створення педагогічних програмних продуктів [14].

Алгоритмічну лінію як одну 3 основних в «архітектоніці» інформатики виокремлюють С.О. Бешенков, С.О. Кузнецов та інші. Навчання інформатики вчені пропонують розглядати не як просте усвідомлення змісту предмета інформатика, а як розвиток інформатичної культури, формування практичних умінь реалізовувати інформаційні процеси в освітній та професійній діяльності [13, С. 246].

Однак, незважаючи на значну кількість досліджень, присвячених формуванню алгоритмічного мислення учнів та майбутніх вчителів інформатики, сьогоднішній етап розвитку шкільної інформатики вимагає внесення суттєвих змін в компоненти методичної підготовки майбутніх вчителів інформатики і в першу чергу в зміст алгоритмічної підготовки, в систему засобів формування алгоритмічного мислення.

Мета авторів даного дослідження полягає у проведенні аналізу сучасних вимог до рівня сформованості алгоритмічного мислення учнів 5-9 класів в курсі інформатики, у визначенні переліку знань та умінь, якими повинен володіти майбутній учитель інформатики для формування цього мислення, переліку комп'ютерних засобів, які необхідні для забезпечення реалізації відповідної змістової лінії.

Експерименти стосовно навчання школярів основ інформатики розпочалися в СРСР практично відразу після створення перших електронно-обчислювальних машин в кінці 60-х на початку 70-х років XX століття. 31975 року вводяться перші факультативні курси, а з 1985 року предмет «Основи інформатики та обчислювальної техніки» став обов'язковим для вивчення в старших класах середньої школи. Автори першої програми, підручників та методичних рекомендацій до навчання інформатики 3 самого початку визначають інформатику фундаментальним компонентом загальної середньої освіти. «Вивчення інформатики закладас наукову базу для формування важливих світоглядних уявлень про можливості автоматизації різних видів діяльності людини на основі алгоритмів» $[5$, С. 5-6].

Основним завданням нового курсу стає формування у школяра певного рівня алгоритмічної культури, під якою А.П. Єршов, В.М. Монахов та інші розуміють частину математичної культури, володіння якою «сприяс формуванню та розвитку уявлень і умінь, пов'язаних з розуміння суті поняття алгоритму та його властивостей»). На їх думку алгоритмізація і навички програмування, що формуються у учнів в процесі навчання інформатики, сприяють розвитку математичних здібностей, творчості, активізують розумову діяльність школярів [5, С. 6]

Уже в початковий період навчання інформатики в школі автори курсу говорять про практичний, прикладний характер нової дисципліни: «Основною задачею школи $\epsilon$ підготовка учнів до використання ЕОМ в майбутній практичній діяльності. Тому у визначенні змісту комп'ютерної грамотності доцільно спиратися на поняття «користувач ЕОМ»» [5, С. 7].

На цій підставі можна стверджувати, що наступний етап розвитку шкільної інформатики, який дістав назву «користувацького» є логічним розвитком принципів, що лягли в основу першого курсу інформатики. Тільки на період початку 90 -х років XX століття зміст діяльності «користувача комп'ютера» змінився. Ї̈ основу складало використання різноманітних прикладних програм для персональних комп'ютерів.

Одним з перших посібників цього етапу розвитку шкільного курсу інформатики, став посібник для вчителів М.І. Шкіля, М.І. Жалдака, Н.В. Морзе та Ю.С. Рамського «Вивчення мов програмування в школі» [6]. У посібнику вперше була досить детально описана структура змісту інформатики в середній школі з врахуванням необхідності до початку вивчення програмування сформувати в учнів навички роботи 3 комп'ютером, 3 його різноплановим програмним забезпеченням. Це був прогресивний крок, який надав можливість учням краще підготуватись до використання комп'ютерної техніки в різних сферах професійної діяльності.

Разом 3 тим, констатуючи необхідність спрямування навчання на розширення ознайомлення школярів та майбутніх учителів інформатики 3 прикладними комп'ютерними програмами, ні А.П. Єршов, ні М.І. Жалдак 3 колегами не передбачали повної відмови від алгоритмізації та 
програмування в шкільній інформатиці. «...Інформація, ЕОМ, алгоритм - три фундаментальних поняття інформатики» [6, С. 6].

Однак, як зазначає С.А. Раков, «загальне позиціонування шкільної інформатики як дисципліни технологічної галузі освіти призвело до кричущої нестабільності методичних систем їі навчання: як можна спиратися виключно на інформаційні технології, якщо їх розвиток настільки стрімкий, що технологічно-орієнтований підручник 3 інформатики може застаріти вже в момент виходу 3 друку?» [16].

У цей період в окремих педагогічних університетах практикувалось поєднання підготовки вчителя інформатики на основі першої гуманітарної (вчитель іноземної мови) або природничої (вчитель біологіі) спеціальності без фундаментальної математичної підготовки.

Думку С.А. Ракова про те, що технологічний перекіс у навчанні інформатики є згубним, підтримав Ю. С. Рамський, який зазначив, що «при реалізації користувацького підходу проявилися деякі негативні наслідки, зокрема пов'язані з послабленням уваги до базової, фундаментальної підготовки 3 інформатики (стосується особливо вищої школи)». Вчений, відзначивши перспективність переходу до парадигми користувацького підходу, пропонує спочатку здійснювати підготовку користувача відповідного рівня, а на цій основі вивчати в певному обсязі та на певному рівні алгоритмізацію та програмування в залежності від типу та профілю навчального закладу чи спеціалізації класів [17].

Перехідним етапом від користувацького підходу до подальшої фундаменталізації змісту шкільної інформатики, в якому частково реалізовувались пропозиції Ю.С. Рамського, стали програми навчання інформатики, починаючи 3 9-го класу [7-10]. Алгоритмізації та програмування пропонувалось навчати за рівнем стандарту та академічним в 11-му класі, а в класах інформаційнотехнологічного профілю - протягом 10-11 класів. Ще одним варіантом навчання інформатики стали програми для класів 3 поглибленим навчанням інформатики з 8-го по 11-й клас. Характеристики змісту та кількості годин на вивчення алгоритмізації та програмування для зазначених профілів та поглибленого вивчення інформатики подано в таблиці 1.

Як видно 3 наведеної таблиці, більшість учнів середньої школи, а за рівнем стандарту інформатику вивчали до 80 \% старшокласників в Україні, після завершення курсу інформатики мали тільки загальні уявлення про алгоритми і зовсім не мали навичок програмування. Відсутність потреби у навчанні учнів програмування, а також інших фундаментальних основ інформатики «віддзеркалювалися й у вищій педагогічній школі: так, замість того, щоб навчати майбутніх учителів інформатики досліджувати, моделювати засобами інформаційних технологій, курс «Нові інформаційні технології» найчастіше зводиться до навчання користування конкретним офісним пакетом» [17].

Як зазначав M.I. Жалдак, не навчаючи учнів розв'язувати задачі з основ алгоритмізації та програмування, учителі самі втрачають вміння їх розв'язувати. Розглядаючи основи алгоритмізації та програмування як складові математичної підготовки майбутніх вчителів, вчений вказує на певне ії послаблення в окремих університетах [3].

Відомості про зміст розділу «Основи алгоритмізації та програмування» за програмами інформатики 2008-2010 років

\begin{tabular}{|c|c|c|c|c|}
\hline \multirow{2}{*}{ 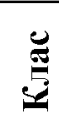 } & \multicolumn{3}{|c|}{ Профі.ль навчання } & \multirow{2}{*}{$\begin{array}{c}\text { Поглиб.лене вивчення } \\
\text { інформатики }\end{array}$} \\
\hline & Стандартний & Академічний & $\begin{array}{l}\text { Інформаційно- } \\
\text { технологічний }\end{array}$ & \\
\hline 1 & 2 & 3 & 4 & 5 \\
\hline 8 & & & & $\begin{array}{l}53 \text { години } \\
\text { Основи алгоритмізаціi ma } \\
\text { програмування: } \\
\text { Основні } \\
\text { алгоритмізації. } \\
\text { Моделі таняття моделювання } \\
\text { Мови програмування. Лінійні } \\
\text { алгоритми. Алгоритми } \\
\text { розгалуженнями. Алгоритми } \\
\text { повтореннями }\end{array}$ \\
\hline 9 & & & & $\begin{array}{l}52 \text { години } \\
\text { Основи алгоритмізації та } \\
\text { програмування } \\
\text { Масиви. Допоміжні }\end{array}$ \\
\hline
\end{tabular}




\begin{tabular}{|c|c|c|c|c|}
\hline \multirow{3}{*}{$\underset{ت}{2}$} & \multicolumn{3}{|c|}{ Профіль навчання } & \multirow{2}{*}{$\begin{array}{l}\text { Поглиблене вивчення } \\
\text { інформатики }\end{array}$} \\
\hline & Стандартний & Академічний & $\begin{array}{l}\text { Інформаційно- } \\
\text { технологічний }\end{array}$ & \\
\hline & & & & \begin{tabular}{lrr} 
алгоритми. & Додаткові & типи \\
змінних. & Створення & та \\
розробка & навчальних \\
проектів. & \multicolumn{2}{c}{} \\
\end{tabular} \\
\hline 10 & & & 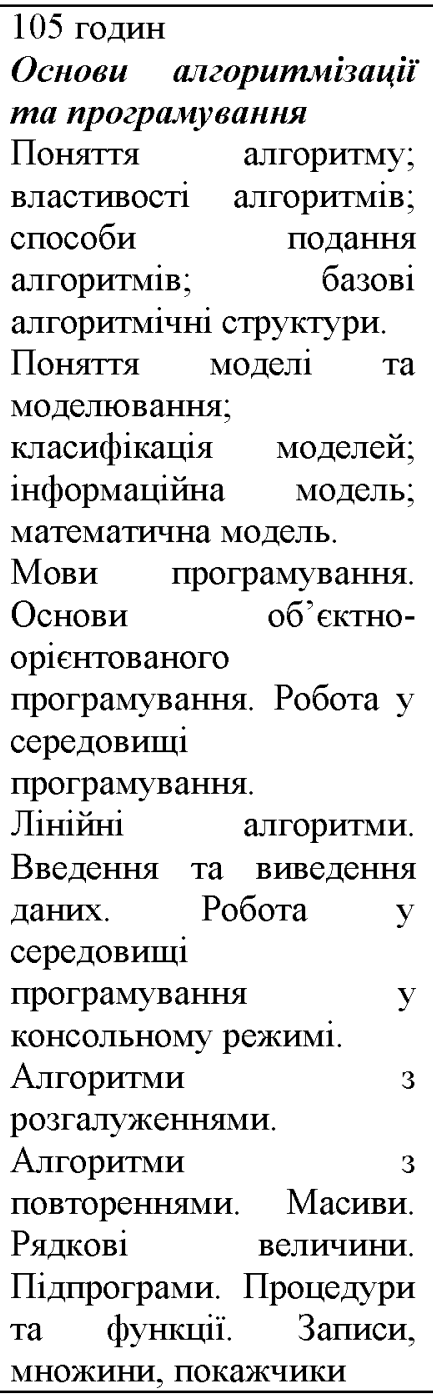 & $\begin{array}{l}\text { 105 годин } \\
\text { Алгоритмізація } \\
\text { програмування } \\
\text { Методика } \\
\text { алгоритмів, побудови } \\
\text { ефективності. } \\
\text { Подання даних у комп'ютері. } \\
\text { Алгоритми роботи } 3 \text { цілими } \\
\text { числами в у різних системах } \\
\text { числення. } \\
\text { Структури даних. } \\
\text { Пошукові алгоритми. } \\
\text { Методи сортування. } \\
\text { Алгоритми для роботи } \\
\text { довгим числами. } \\
\text { Застосування } \\
\text { комбінаторики елементів } \\
\text { розв'язування алгоритмічних } \\
\text { задач. } \\
\text { NР-повні задачі. } \\
\text { Основи теорії графів. } \\
\text { Основи } \\
\text { програмування. динамічного } \\
\text { Жадібні алгоритми. } \\
\text { Алгоритми обчислювальної } \\
\text { геометрії. }\end{array}$ \\
\hline 11 & $\begin{array}{l}8 \text { годин } \\
\text { Моделювання. } \\
\text { Основи } \\
\text { алгоритмізації: } \\
\text { Поняття } \\
\text { алгоритму. } \\
\text { Властивості } \\
\text { алгоритмів. } \\
\text { Форми подання } \\
\text { алгоритму. } \\
\text { Поняття про мови } \\
\text { програмування }\end{array}$ & $\begin{array}{l}28 \text { годин } \\
\text { Основи } \\
\text { алгоритмізаціï } \\
\text { та } \\
\text { програмування } \\
\text { Поняття } \\
\text { алгоритму, } \\
\text { властивості } \\
\text { алгоритмів. } \\
\text { Форми подання } \\
\text { алгоритмів. } \\
\text { Графічне } \\
\text { подання } \\
\text { алгоритмів. } \\
\text { Поняття мови } \\
\text { програмування, } \\
\text { програмного } \\
\text { коду, } \\
\text { середовища } \\
\text { розробки } \\
\text { програм, }\end{array}$ & $\begin{array}{l}70 \text { годин } \\
\text { Алгоритмізація ma } \\
\text { програмування } \\
\text { Структури даних. } \\
\text { Основи теорії графів. } \\
\text { Елементи оби } \\
\text { обчислювальної геометрії } \\
\text { Основи об'єктно- } \\
\text { орієнтованого } \\
\text { проектування. } \\
\text { Проектування об'єктно- } \\
\text { орієнтованої архітектури. } \\
\text { Проектування } \\
\text { програмної логіки за } \\
\text { допомогою діаграм } \\
\text { діяльності мови UML. } \\
\text { Графіка у мові об'єктно- } \\
\text { орієнтованого } \\
\text { програмування. } \\
\text { Мультимедійні } \\
\text { особливості об'єктно- }\end{array}$ & 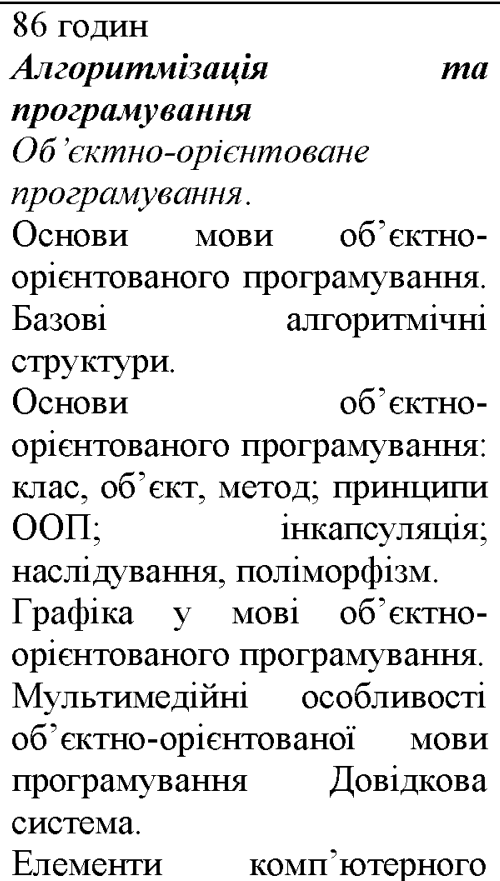 \\
\hline
\end{tabular}




\begin{tabular}{|c|c|c|c|c|}
\hline \multirow[b]{2}{*}{$\stackrel{\mathscr{w}}{2}$} & \multicolumn{3}{|c|}{ Профі.ль навчання } & \multirow{2}{*}{$\begin{array}{c}\text { Поглиблене вивчення } \\
\text { інформатики }\end{array}$} \\
\hline & Стандартний & Академічний & $\begin{array}{l}\text { Iнформаційно- } \\
\text { технологічний }\end{array}$ & \\
\hline & & $\begin{array}{l}\text { компілятора. } \\
\text { Основи } \\
\text { структурного } \\
\text { програмувания } \\
\text { Основні } \\
\text { поняття } \\
\text { математичної } \\
\text { логіки. } \\
\text { Запис логічних } \\
\text { виразів мовою } \\
\text { програмування. } \\
\text { Алгоритмічна } \\
\text { конструкція } \\
\text { розгалуження. } \\
\text { Поняття } \\
\text { підпрограми та } \\
\text { іï аргументів. } \\
\text { Алгоритмічна } \\
\text { конструкція } \\
\text { повторення. } \\
\text { Поняття } \\
\text { масиву. }\end{array}$ & 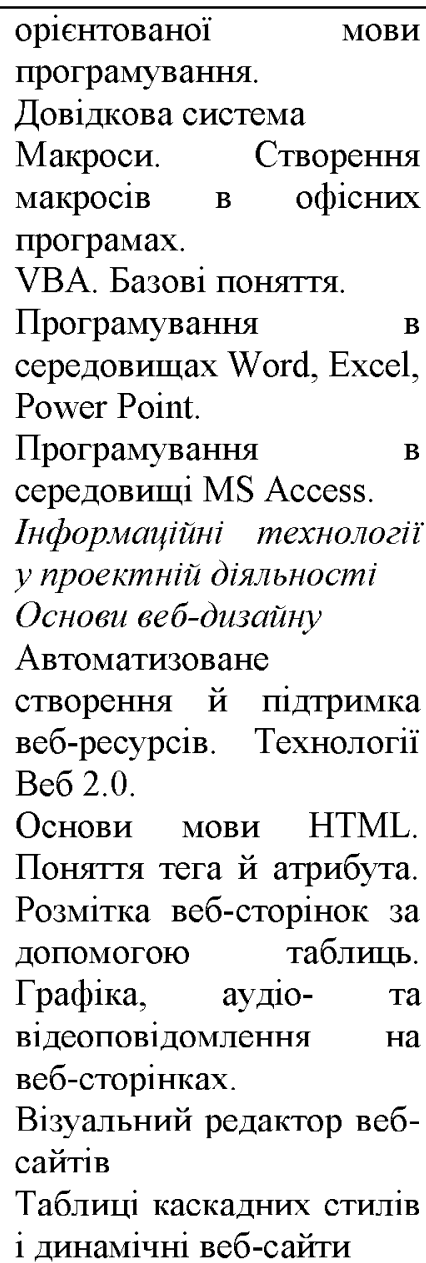 & 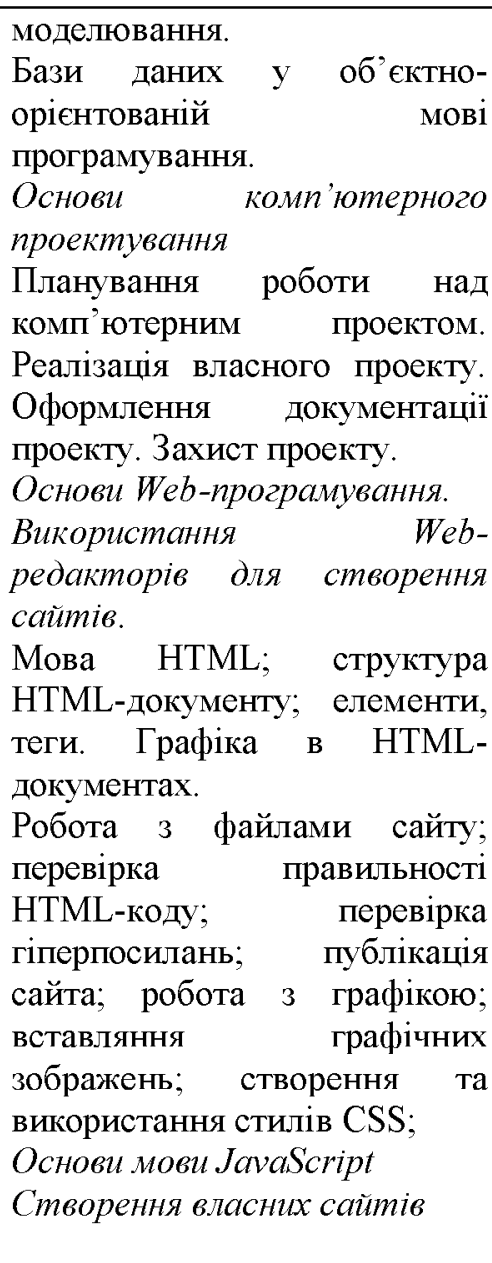 \\
\hline
\end{tabular}

Інформація, інформаційні

процеси, системи, технології

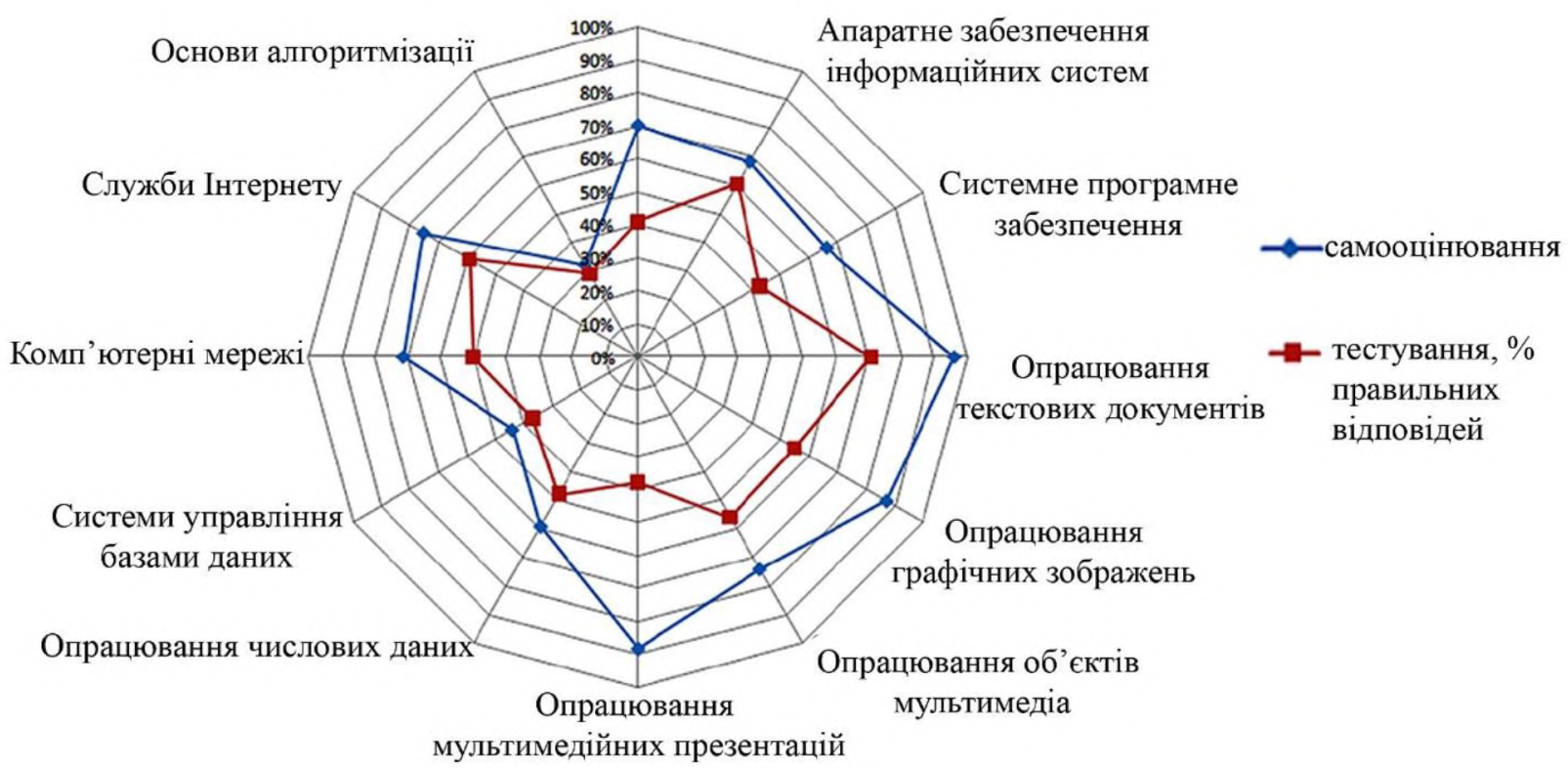

Рис. 1. Діаграма виконання завдань вчителями

Про рівень підготовленості учителів до навчання учнів різних складових курсу інформатики свідчать дослідження, проведені в Миколаївському обласному інституті післядипломної освіти протягом 2014-2016 років. Було проведено моніторинг рівня сформованості складових інформаційнокомунікаційних компетентностей учителів інформатики загальноосвітніх навчальних закладів 
Миколаївської області. До участі в моніторингу залучено біля 500 учителів (більше $85 \%$ від загальної кількості учителів інформатики області) [4].

В дослідженні передбачалося на першому етапі самооцінювання, а на другому - виконання тестових завдань 3 фундаментальних питань інформатики (Інформація, інформаційні процеси, системи, технології; Основи алгоритмізації; Апаратне забезпечення інформаційних систем) та особливостей роботи з інформаційними технологіями (Системне програмне забезпечення; Створення та опрацювання: текстових документів; графічних зображень; об'єктів мультимедіа; мультимедійних презентацій; числових даних; Системи управління базами даних; Комп'ютерні мережі; Служби мережі Інтернет). Тематика розділів моніторінгу та зміст завдань корелювалися 3 вимогами сформульованими у програмі 3 інформатики для середньої школи. Аналіз отриманих результатів моніторингу дає підстави стверджувати, що, як зазначає О.Г. Захар, найскладнішими для вчителів виявилися «питання стосовно теоретичних фундаментальних знань з інформатики, а саме інформація, інформаційні процеси, алгоритми...» [4]. Крім того основи алгоритмізації - це єдиний розділ моніторингу, з якого самооцінка вчителів практично співпадає з результатами виконання завдань (рис. 1). А результати - найнижчі та становлять лише біля $30 \%$ правильно виконаних завдань.

Наступний етап розвитку шкільної інформатики, який розпочався із введенням інформатики 3 2-го класу початкової та з 5-го класу основної школи характеризується, як зазначас С.А. Раков [16], фундаменталізацією змісту інформатики. Це підтверджується аналізом програми з інформатики для учнів 5-9 класів [11]. В таблиці 2 подано основні питання предметної змістової лінії «Моделювання, алгоритмізація й програмування».

Таблиця 2

Предметна змістова лінія «Моделювання, алгоритмізація й програмування» в програмі 3 інформатики для загальноосвітніх навчальних закладів (5-9 класи)

\begin{tabular}{|c|c|c|}
\hline Клас & $\begin{array}{c}\text { Очікувані результати навчально-пізнавальної } \\
\text { діяльності учнів }\end{array}$ & $\begin{array}{l}\text { Зміст навчального } \\
\text { матеріалу }\end{array}$ \\
\hline 5 & $\begin{array}{l}\text { Учень/учениця } \\
\text { Знаннєва складова } \\
\text { Пояснює понятя алгоритму та програми. } \\
\text { Наводить приклади виконавців та команд, які вони } \\
\text { виконують. } \\
\text { Пояснює сутність алгоритмічних структур. } \\
\text { Діяльнісна складова } \\
\text { Складає прості алгоритми. } \\
\text { Розрізняс алгоритмічні структури. } \\
\text { Використовує середовище для опису та виконання } \\
\text { алгоритмів. } \\
\text { Обирає алгоритмічні структури для розв'язування } \\
\text { поставленої задачі. } \\
\text { За необхідності коригує алгоритми. } \\
\text { Виконує алгоритми, подані у формальному вигляді }\end{array}$ & $\begin{array}{l}\text { Виконавці алгоритмів та їх } \\
\text { системи команд. } \\
\text { Способи опису алгоритму. } \\
\text { Програма. } \\
\text { Середовище опису й } \\
\text { виконання алгоритмів. } \\
\text { Лінійні алгоритми. } \\
\text { Алгоритми з розгалуженнями. } \\
\text { Алгоритми з повтореннями }\end{array}$ \\
\hline 6 & 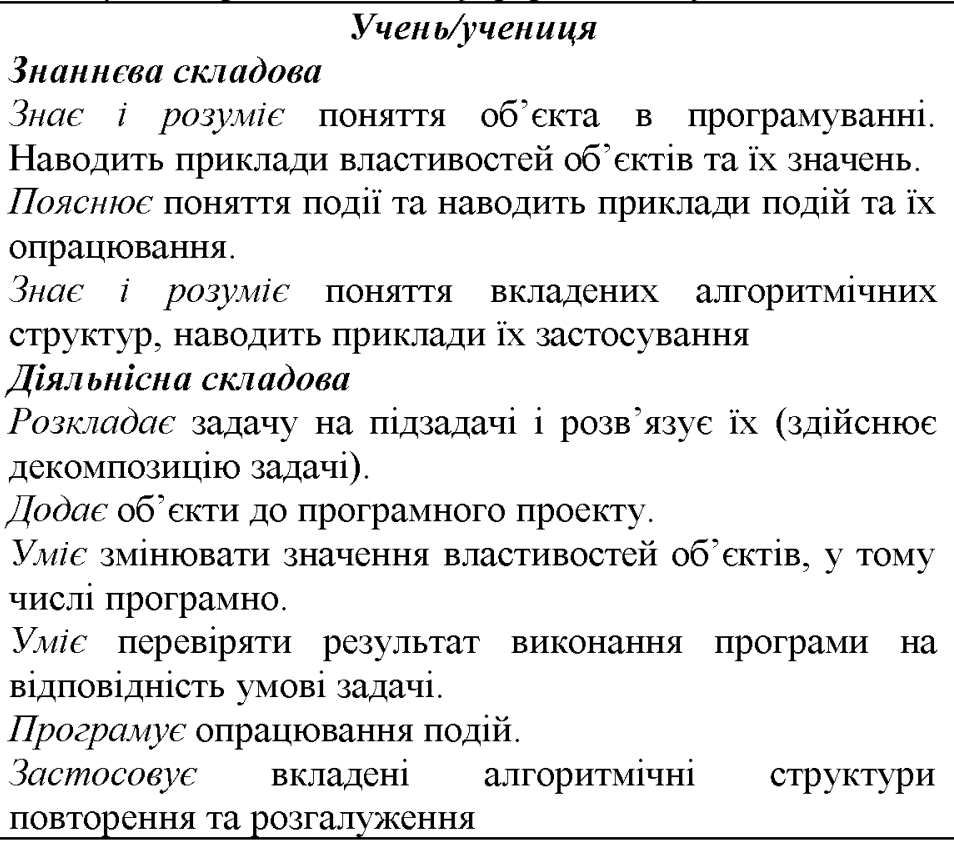 & 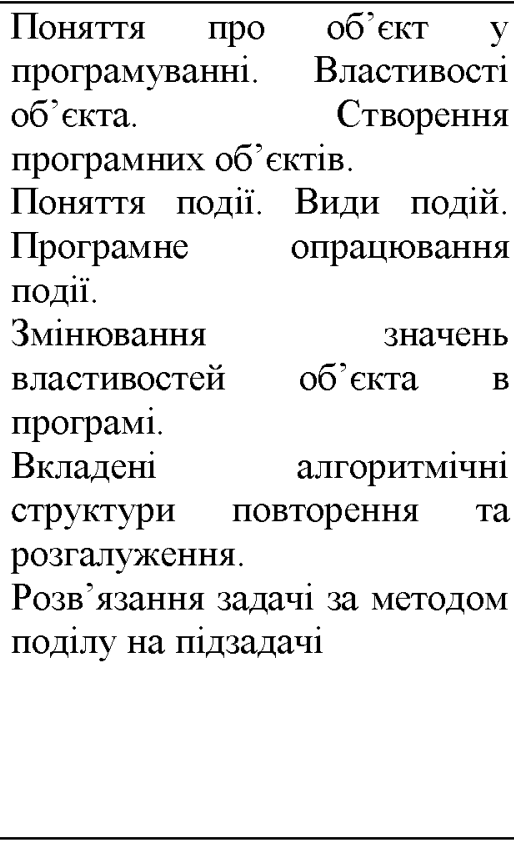 \\
\hline
\end{tabular}




\begin{tabular}{|c|c|c|}
\hline Клас & $\begin{array}{c}\text { Очікувані результати навчально-пізнавальної } \\
\text { діяльності учнів }\end{array}$ & $\begin{array}{l}\text { Зміст навчального } \\
\text { матеріалу }\end{array}$ \\
\hline 7 & $\begin{array}{l}\text { Учень/учениця } \\
\text { Знаннєва складова } \\
\text { Пояснює поняття величини, змінної та операції надання } \\
\text { значень. } \\
\text { Знає базові алгоритми роботи зі змінними: обмін } \\
\text { значенням, визначення найбільшого й найменшого } 3 \\
\text { двох значень } \\
\text { Діяльнісна складова } \\
\text { Використовує різні алгоритмічні структури та змінні } \\
\text { для розв'язування навчальних і життєих задач. } \\
\text { Застосовус засоби програмування для побудови } \\
\text { моделей }\end{array}$ & $\begin{array}{ll}\text { Величини. } & \text { Змінні. Вказівка } \\
\text { надання значень. } \\
\text { Створення } \\
\text { програм алгоритмів } \\
\text { змінних } & \text { використанням } \\
\text { алгоритмічних } & \text { р структур } \\
\text { лінійних, розгалужень } \\
\text { повторень. } \\
\text { Опис моделей у середовищі } \\
\text { програмування }\end{array}$ \\
\hline 8 & 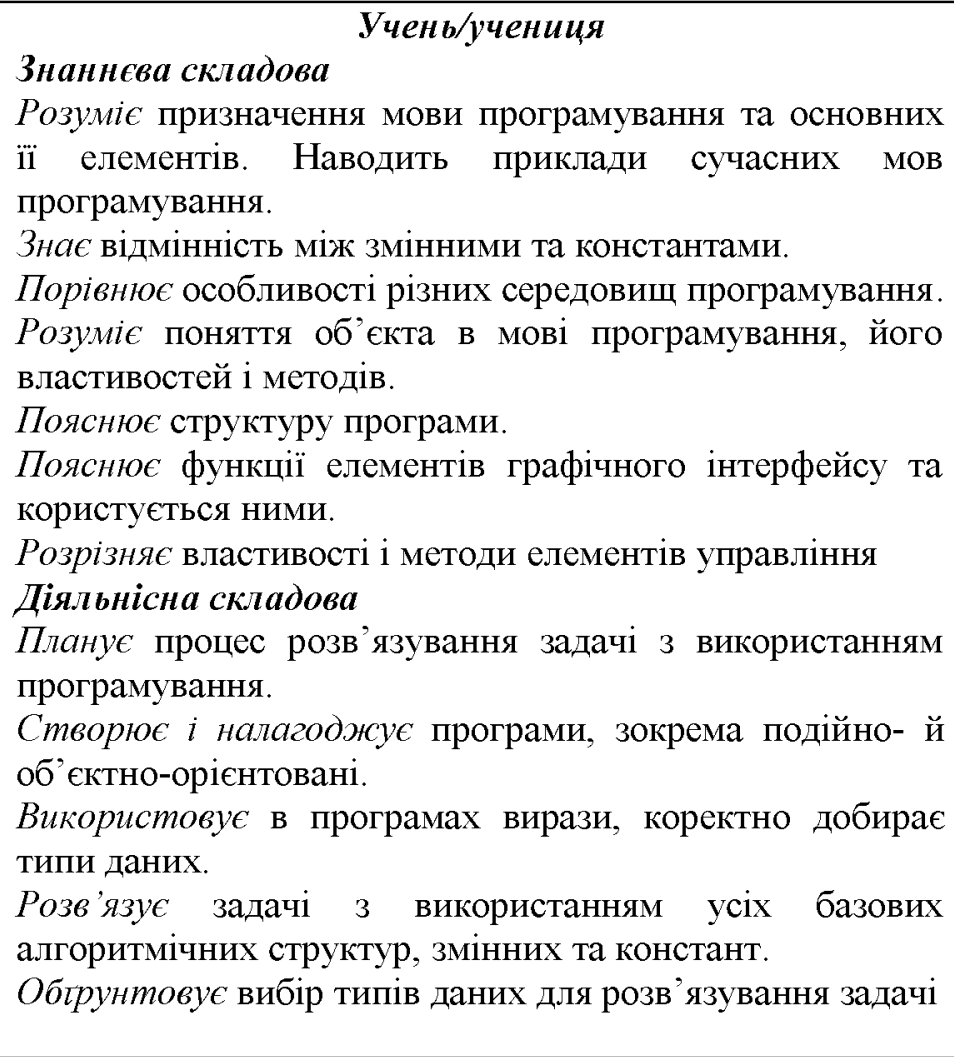 & 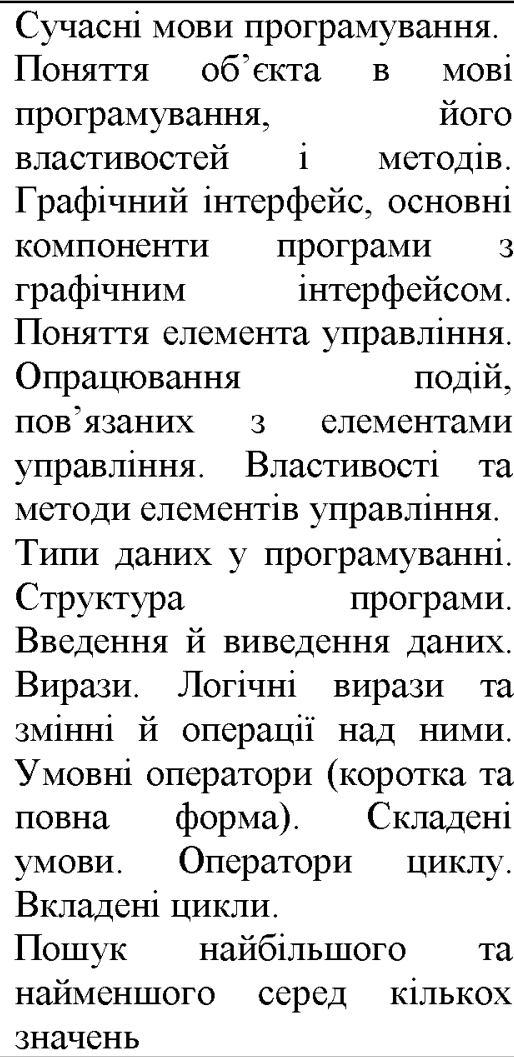 \\
\hline 9 & 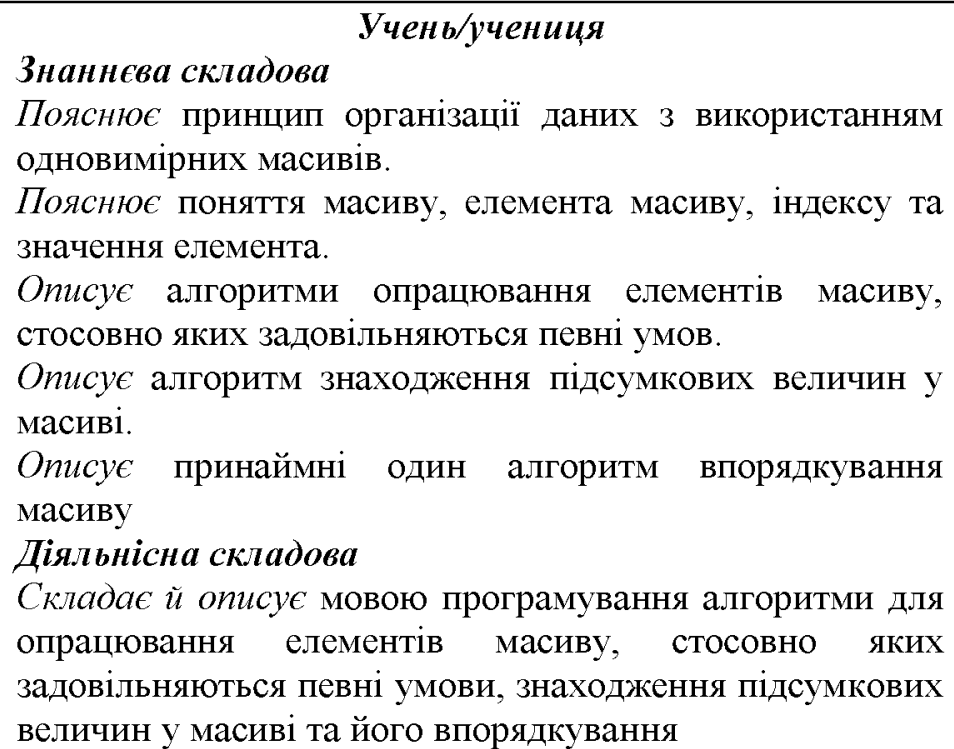 & 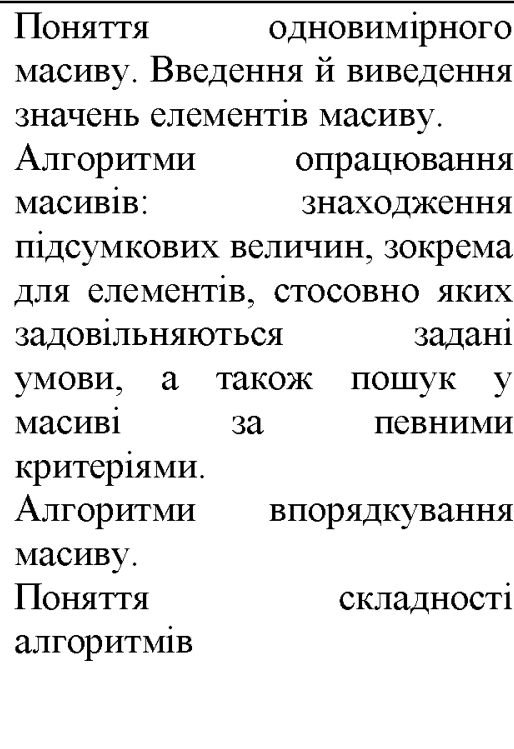 \\
\hline
\end{tabular}

Важливість предметної змістової «Моделювання, алгоритмізація та програмування» підкреслюються вимогами планувати не менше $40 \%$ навчального часу в 5-8 класах і не менше $30 \%$ 
у 9 класі на вивчення цієї змістової лінії [11]. Вона є найбільшою за обсягами часу, який повинен плануватись на ії вивчення: не менше 91 години з 245.

Ці вимоги повинні знайти своє відображення в змісті підготовки майбутніх вчителів інформатики. Як зазначає М. І. Жалдак, «Учитель повинен мати до певної міри універсальні, фундаментальні знання, щоб мати можливість ефективно, педагогічно доцільно і виважено використовувати засоби сучасних інформаційно-комунікаційних технологій у навчальному процесі, створювати для дітей умови для повного розкриття їхнього творчого потенціалу... Головними діючими особами в навчальному процесі залишаються учні і вчителі... I тільки від обізнаності і майстерності вчителя, його творчості і винахідливості залежать ефективність і результативність навчально-пізнавальної діяльності учнів» [3].

Аналіз результатів проведеного дослідження поглядів вчених на структуру змісту професійної підготовки майбутніх учителів інформатики, аналізу моніторингу сформованості професійних знань і вмінь учителів загальноосвітніх навчальних закладів, аналізу вимог до результатів навчання 3 інформатики, сформульованих в програмах шкільного курсу інформатики дозволяє зробити такі висновки:

3 початку введення курсу інформатики в загальноосвітні навчальні заклади науковці, автори державних стандартів, програм, підручників обов'язковою складовою курсу вважали і вважають змістову лінію 3 основ алгоритмізації та програмування, зміст якої відносять до фундаментальних основ інформатики.

Обсяги вивчення основ алгоритмізації та програмування в різні періоди розвитку шкільної інформатики дуже сильно відрізнялися. В програмах, за якими на даний момент навчають інформатики в школі, передбачасться вивчення основ алгоритмізації та програмування в обсязі не менше $37 \%$ від загальної кількості годин, що суттєво більше ніж в попередні 15-20 років.

Значне збільшення кількості годин на вивчення основ алгоритмізації та програмування в середній школі, вивчення кількох мов програмування, web-програмування потребує посилення фундаменталізації змісту підготовки майбутніх вчителів інформатики, особливо з теорії алгоритмів та програмування.

На черговому етапі оновлення змісту середньої освіти передбачається необхідність подальших досліджень для обгрунтування цілей навчання інформатики, напрямів оновлення ії змісту, внесення змін у систему підготовки вчителів інформатики у вищих педагогічних навчальних закладах.

На основі проведеного дослідження планується науково та методично обгрунтувати зміст підготовки майбутніх учителів інформатики 3 врахуванням програмових вимог шкільної інформатики, перелік мов програмування для вивчення майбутніми вчителями інформатики, дібрати систему завдань для формування навичок програмування різними мовами.

\section{Список використаних джерел:}

1. Андрей Петрович Ершов - ученый и человек / ред.-сост. М. А. Бульонков [и др.]; отв. ред. А.Г. Марчук; Рос. акад. наук, Сиб. отд-ние, Ин-т сист. информатики им. А. П. Ершова. Новосибирск: Издательство СО РАН, 2006. 505 с. (Наука Сибири в лицах).

2. Ершов А.П. Предисловие редактора // Новые задачи информатики: Сб. науч. тр. / Под ред. А.П. Ершова. Новосибирск, 1979. Архив академика А.П. Ершова. Папка 242. Разное (черновики статей, стенограмма вопросов и ответов, выступления на митинге и проч.). Поездка в Болгарию (июнь, 1979 г.) и отчет. Л. 217. URL: http://ershov.iis.nsk.su/archive

3. Жалдак M. I. Інформатика - фундаментальна наукова дисципліна. Вона має вивчати закони природи, інформаційні процеси і відповідні технології. Комп'ютер у иколі та сім'ї. 2010. №3. с. 711.

4. Захар О.Г. Шляхи формування інформаційно комунікаційної компетентності вчителів інформатики Миколаївської області. Комп'ютер у иколі та сім' ̈̈. 2016. №7. с. 45-51.

5. Изучение основ информатики и вычислительной техники: Методическое пособие для учителей и преподавателей средних учебных заведений: В 2 ч. / А. П. Ершов и др.; Под ред. А.П. Ершова, В. М. Монахова. Москва: Просвещение, 1986. Ч. 1. 172 с.; Ч. 2.207 с.

6. Шкиль Н. И., Жалдак М. И., Морзе Н. В., Рамский Ю. С. Изучение языков программирования в школе: пособие для учителя. Киев: Рад. шк., 1988. 272 с.

7. Інформатика: навчальна програма для 10-11 класів інформаційно-технологічного профілю. Київ: Міністерство освіти і науки. 2009. 82 с. URL: http://old.mon.gov.ua/images/education/average/ prog $12 /$ prof riven.doc

8. Інформатика: навчальна програма для учнів 10-11 класів загальноосвітніх навчальних закладів: рівень стандарту. Київ: Міністерство освіти і науки. 2009. 25 с. URL: http://old.mon.gov.ua/ images/education/average/prog12/inf st.doc 
9. Інформатика: навчальна програма для учнів 10-11 класів загальноосвітніх навчальних закладів: академічний рівень. Київ: Міністерство освіти i науки. 2009. 29 с. URL: http://old.mon.gov.ua/images/education/average/progl2/inf ak.doc

10. Інформатика : навчальна програма для учнів 9 класу загальноосвітніх навчальних закладів / I.O. Завадський та ін. Київ: Міністерство освіти і науки, 2008. 22 с. URL: http://www.mon.gov.ua/ img/zstored/files/inf.doc

11. Інформатика. Програма курсу. 5-9 класи загальноосвітніх навчальних закладів Київ: Міністерство освіти і науки, 2017. 66 c. URL: https://mon.gov.ua/storage/app/media/zagalna\%20serednva/ programv-5-9-klas/onovlennva-12-2017/programa-informatika-5-9-traven-2015.pdf

12. Концепція реалізації державної політики у сфері реформування загальної середньої освіти "Нова українська школа" на період до 2029 року [схвалено розпорядженням Кабінету Міністрів України від 14 грудня 2016 р. № 988-p]. Київ: 2016. 5 c. URL: https://www.kmu.gov.ua/storage/app/ imported content/npa/249613934/249613934.doc

13. Об информатике, ее подходах и предмете (философия информатики) / А. А. Кузнецов и др. Вестник ТГУ, т.10, вып.3, 2005. С. 236-249

14. Никитин П. В., Горохова Р. И., Мельникова А. И. К вопросу о формировании предметных компетенций в области информационных технологий будущих учителей информатики. Электронный журнал «Вестник МГОУ» 2013. № 4. С. 1-8. URL: www.evestnik-mgou.ru.

15. Раков С.А. Сучасний учитель інформатики: кваліфікація і вимоги. Комп'ютер у иколі та сім'і. 2005. №3. С. 35-38.

16. Раков С.А. Проблеми інформатичної освіти в Україні. Комп'ютер у иколі та сім'ї. 2010. №2. c. 34-35.

17. Рамський Ю. С. Підвищення рівня фундаментальної підготовки з інформатики майбутніх вчителів математики та інформатики. Науковий часопис НПУ імені М. П. Драгоманова. Серія № 2. Комп'ютерно-орієнтовані системи навчання. Київ: НПУ імені М. П. Драгоманова, 2010. № 9 (16). C. 95-98.

\section{References:}

1. Andrej Petrovich Ershov - uchenyj i chelovek / red.-sost. M. A. Bul'onkov [i dr.]; otv. red. A.G. Marchuk; Ros. akad. nauk, Sib. otd-nie, In-t sist. informatiki im. A. P. Ershova. Novosibirsk: Izdatel'stvo SO RAN, 2006. $505 \mathrm{~s}$. (Nauka Sibiri v licah).

2. Ershov A.P. Predislovie redaktora // Novye zadachi informatiki: Sb. nauch. tr. / Pod red. A.P. Ershova. Novosibirsk, 1979. Arhiv akademika A.P. Ershova. Papka 242. Raznoe (chernoviki statej, stenogramma voprosov i otvetov, vystuplenija na mitinge i proch.). Poezdka v Bolgariju (ijun', 1979 g.) i otchet. L. 217. URL: http://ershov.iis.nsk.su/archive

3. Zhaldak M. I. Informatyka - fundamentalna naukova dystsyplina. Vona maie vyvchaty zakony pryrody, informatsiini protsesy i vidpovidni tekhnolohii. Kompiuter u shkoli ta simi . 2010. №3. s. 7-11.

4. Zakhar O. H. Shliakhy formuvannia informatsiino komunikatsiinoi kompetentnosti vchyteliv informatyky Mykolaivskoi oblasti. Kompiuter u shkoli ta simi. 2016. №7. s. 45-51.

5. Izuchenie osnov informatiki i vychislitel'noj tehniki: Metodicheskoe posobie dlja uchitelej i prepodavatelej srednih uchebnyh zavedenij: V 2 ch. / A. P. Ershov i dr.; Pod red. A.P. Ershova, V.M. Monahova. Moskva: Prosveshhenie, 1986. Ch. 1. 172 s.; Ch. 2. 207 s.

6. Shkil' N. I., Zhaldak M. I., Morze N. V., Ramskij Ju. S. Izuchenie jazykov programmirovanija v shkole: posobie dlja uchitelja. Kiev: Rad. shk., 1988. $272 \mathrm{~s}$.

7. Informatyka: navchalna prohrama dlia 10-11 klasiv informatsiino-tekhnolohichnoho profiliu. Kyiv: Ministerstvo osvity i nauky. 2009. 82 s. URL: http://old.mon.gov.ua/images/education/average /prog $12 /$ prof riven.doc

8. Informatyka: navchalna prohrama dlia uchniv 10-11 klasiv zahalnoosvitnikh navchalnykh zakladiv: riven standartu. Kyiv: Ministerstvo osvity i nauky. 2009. 25 s. URL: http://old.mon.gov.ua/images/ education/average/prog $12 / \mathrm{inf}$ st.doc

9. Informatyka: navchalna prohrama dlia uchniv 10-11 klasiv zahalnoosvitnikh navchalnykh zakladiv: akademichnyi riven. Kyiv: Ministerstvo osvity i nauky. 2009. 29 s. URL: http://old.mon.gov.ua/images/ education/average/prog $12 /$ inf ak.doc

10. Informatyka : navchalna prohrama dlia uchniv 9 klasu zahalnoosvitnikh navchalnykh zakladiv / I.O. Zavadskyi ta in. Kyiv: Ministerstvo osvity i nauky, 2008. 22 s. URL: http://www.mon.gov.ua/img/ zstored/files/inf.doc

11. Informatyka. Prohrama kursu. 5-9 klasy zahalnoosvitnikh navchalnykh zakladiv Kyiv: Ministerstvo osvity i nauky, 2017. $66 \mathrm{~s}$. URL: https://mon.gov.ua/storage/app/media/zagalna\%20serednva/programv-5-9klas/onovlennva-12-2017/programa-informatika-5-9-traven-2015.pdf 
12. Kontseptsiia realizatsii derzhavnoi polityky u sferi reformuvannia zahalnoi serednoi osvity "Nova ukrainska shkola" na period do 2029 roku [skhvaleno rozporiadzhenniam Kabinetu Ministriv Ukrainy vid 14 hrudnia 2016 r. № 988-r]. Kyiv: 2016. 5 s. URL: https://www.kmu.gov.ua/storage/app/imported content/ npa/249613934/249613934.doc

13. Ob informatike, ee podhodah i predmete (filosofija informatiki) / A. A. Kuznecov i dr. Vestnik TGU, t. 10, vyp.3, 2005. S. 236-249

14. Nikitin P. V., Gorohova R. I., Mel'nikova A. I. K voprosu o formirovanii predmetnyh kompetencij v oblasti informacionnyh tehnologij budushhih uchitelej informatiki. Jelektronnyj zhurnal «Vestnik MGOU» 2013. № 4. S. 1-8. URL: www.evestnik-mgou.ru.

15. Rakov S.A. Suchasnyi uchytel informatyky: kvalifikatsiia i vymohy. Kompiuter u shkoli ta simi. 2005. №3. S. 35-38.

16. Rakov S.A. Problemy informatychnoi osvity v Ukraini. Kompiuter u shkoli ta simi. 2010. №2. s. 34-35.

17. Ramskyi Yu. S. Pidvyshchennia rivnia fundamentalnoi pidhotovky $z$ informatyky maibutnikh vchyteliv matematyky ta informatyky. Naukovyi chasopys NPU imeni M. P. Drahomanova. Seriia №2. Kompiuternooriientovani systemy navchannia. Kyiv : NPU imeni M. P. Drahomanova, 2010. № 9 (16). C. 95-98.

\section{Forming algorithmic competencies of future teachers of informatics at the new stage of educational development}

Kushnir N.O., Shakotko V.V.

Abstract. The views of scientists on the algorithmic component of the future IT teachers' training are analyzed in the article, the links between the contents of the requirements for the professional competences of IT teachers and the content of the curriculum of school computer science at different stages of the development of this discipline are investigated.

A comparative analysis of the requirements for the algorithmic competency level formation of secondary school students according to computer science programs of 2008-2009 and 2017-2018 was conducted. On the basis of this analysis, as well as the results of monitoring the level of teachers' preparedness for teaching students algorithmization and programming, the necessity of making essential changes in the methodical system of training future IT teachers, strengthening of the fundamental component of this system based on the improvement of training on algorithmization and programming has been substantiated.

Keywords: informatics, algorithm, algorithmic competence, training informatics teachers

DOI 10.31392/NPU-nc.series 2.2019.21(28).15

УДК 373.545

O.В. Струтинська

кандидат педагогічних наук, доцент;

М.А. Умрик

кандидат педагогічних наук, доцент

Національний педагогічний університет імені М.П. Драгоманова

\section{ДЕЯКІ АСПЕКТИ НАВЧАННЯ МОВ ТА ТЕХНОЛОГІЙ ПРОГРАМУВАННЯ СИСТЕМ ШТУЧНОГО ІНТЕЛЕКТУ МАЙБУТНІХ МАГІСТРІВ ІНФОРМАТИКИ}

Анотація. У статті аналізуються деякі аспекти навчання мов та технологій програмування майбутніх магістрів інформатики у процесі навчання основ штучного інтелекту. Обгрунтовується можливість впровадження в навчання основи штучного інтелекту модуля „Мови та технології програмування систем штучного інтелекту", призначеного для підготовки майбутніх магістрів інформатики. Навчання курсу повинне сприяти засвоєнню студентами базових знань, що стосуються основ функціонування систем штучного інтелекту, формування відповідних умінь застосування таких систем для розв'язування прикладних задач та оволодіння навичками використання засобів проектування та розробки цих систем. В статті розглянуто можливі шляхи формування у студентів практичних навичок та умінь програмування мовою логічного програмування Prolog в он-лайн середовищі SWI Prolog.

Ключові слова: штучний інтелект, програмування, логічне програмування, мова програмування Prolog, середовище програмування SWI Prolog.

Навчання основ штучного інтелекту майбутніх магістрів інформатики вищого педагогічного навчального закладу на сьогоднішній день $\epsilon$ особливо важливим питанням, оскільки штучний 